\title{
The key role of the redox status in regulation of metabolism in photosynthesizing organisms
}

\author{
Andrzej Kornas', Elżbieta Kuźniak², Ireneusz Ślesak ${ }^{3,4}$ and Zbigniew Miszalski1,3凶 \\ IInstitute of Biology, Pedagogical University, Kraków, Poland; 2Department of Plant Physiology and Biochemistry, University of Łódź, Łódź, Po- \\ land; ${ }^{3}$ Institute of Plant Physiology, Polish Academy of Sciences, Kraków, Poland; 4Warsaw University of Life Sciences, Department of Plant Ge- \\ netics, Breeding, and Biotechnology, Warszawa, Poland
}

The redox status of the cell is described by the ratio of reduced to non-reduced compounds. Redox reactions which determine the redox state are an essential feature of all living beings on Earth. However, the first life forms evolved under strongly anoxic conditions of the young Earth, and the redox status probably was based on iron and sulphur compounds. Nowadays, redox reactions in cells have developed in strict connection to molecular oxygen and its derivatives i.e. reactive oxygen species (ROS). Oxygen has started to accumulate on the Earth due to oxygenic photosynthesis. All aspects of aerobic life involve ROS, reactive nitrogen species (RNS), antioxidants and redox regulation. Many different redox-active compounds are involved in the complex of redox processes, including pyridine nucleotides, thioredoxins, glutaredoxins and other thiol/disulphide-containing proteins. Redox regulation is integrated with the redox-reactions in photosynthesis and respiration to achieve an overall energy balance and to maintain a reduced state necessary for the biosynthetic pathways that are reductive in nature. It underlies the physiological and developmental flexibility in plant response to environmental signals.

Keywords: redox status, evolution, photosynthesis, ROS, hydrogen peroxide, chloroplast

Received: 15 March, 2010, revised: 09 June, 2010; accepted: 16 June, 2010; available on-line: 17 June, 2010

\section{INTRODUCTION}

Higher plants that dominate in terrestrial ecosystems have evolved multiple adaptive strategies to survive and reproduce in the constantly changing environment with respect to temperature, light, $\mathrm{CO}_{2}$, water and nutrient status. Moreover, under natural conditions they suffer from many abiotic and biotic stress factors that usually act in combination, a phenomenon known as multistress (Mittler, 2006). Consequently, plants always respond to a unique complex of growth conditions. Integration of many signals into a comprehensive signalling network to coordinate the regulation of growth and developmental processes under fluctuating environmental conditions is the molecular basis for this flexible response. Advances in our understanding of this mechanism rely on new concepts of oxidative stress and redox signalling commonly attributed to a plant response to environmental constraints.

\section{REDOX STATUS AT THE VERY EARLY STAGE OF EVOLUTION}

Phylogenetic analyses locate the root of the tree in non-photosynthetic microbes (e.g. Pace, 1997; Reysenbach \& Shock, 2002; Olson \& Blankenship, 2004) just between Bacteria and Archaea domains (Zhaxybayeva et al., 2005), although this question is still the subject of hot debates (e.g. Dagan \& Martin, 2006; Di Giulio, 2007; Wong et al., 2007; Mat et al., 2008). Metabolic processes of the pre-photosynthetic biosphere most likely involved energy derived from redox disequilibrium involving $\mathrm{Fe}$, S, C, $\mathrm{H}_{2}$ and $\mathrm{O}_{2}$ (Walker, 1977), and early life depended on energy sources provided by redox disequilibria generated by abiotic mass transfer of geological processes (Canfield et al., 2006; Sleep \& Bird, 2007). Nowadays almost all life on Earth depends ultimately on photosynthetic primary producers (e.g. Holser et al., 1988), and photosynthesis is an ancient process on Earth (Fig. 1). Some ancestral systems were adapted to photoautotrophic photosynthesis in low redox environments and might well have functioned in phototrophic bacteria that used reduced sulphur compounds as electron donors for $\mathrm{CO}_{2}$ fixation (Olson \& Pierson, 1986). The first photosynthetic processes, a huge metabolic innovation, probably developed from a series of pre-adaptations to the environmental conditions of the pre-photosynthetic niches (Sleep \& Bird, 2008). Hydrogen based photosynthesis probably evolved gradually from photocatalysis related to the acetogenesis reaction, which is a form of anoxygenic photosynthesis, and the ability to metabolize iron and sulphur compounds pre-adapted organisms for the use of sulphide and ferric iron as abundant oxygen acceptors. This freed a bacterium from its dependence on redox disequilibrium in geological processes as a source of available energy (Sleep \& Bird, 2008). The most ancient form of anoxygenic photosynthesis may well have used external reductants as reduced sulphur compounds or ferrous iron as electron donors for $\mathrm{CO}_{2}$ fixation (Olson \& Pierson, 1986; Olson \& Blankenship, 2004). There is no standard term and no convenient candidate for the

e-mail: miszalski@ifr-pan.krakow.pl

Abbreviations: AA-GSH, ascorbate-glutathione cycle; D1, protein of the PSII reaction center; EEE, excess energy excitation; HR, hypersensitive response; LHC, light harvesting complex; LUCA, last universal common ancestor; PCD, programmed cell death; PSI, photosystem I; PSII, photosystem II; RC1, reaction center of photosystem I; RC2, reaction center of photosystem II; RNS, reactive nitrogen species; ROS, reactive oxygen species; SOD, superoxide dismutase; RubisCO, ribulose-1,5-bisphosphate carboxylase/oxygenase. 
chemical species that is oxidized during anoxygenic photosynthesis (Sleep \& Bird, 2008), but most likely the following reactions were possible at the early stages of life evolution:

$$
2 \mathrm{CO}_{2}+\mathrm{S}^{-2}+2 \mathrm{H}_{2} \mathrm{O}+b v \rightarrow 2 \mathrm{CH}_{2} \mathrm{O}+\mathrm{SO}_{4}{ }^{-2}
$$

(e.g. Grassineau et al., 2001) and

$$
\mathrm{CO}_{2}+4 \mathrm{FeO}+\mathrm{H}_{2} \mathrm{O}+h v \rightarrow \mathrm{CH}_{2} \mathrm{O}+2 \mathrm{Fe}_{2} \mathrm{O}_{3}
$$

(e.g. Ehrenreich \& Widdel, 1994; Kappler \& Newman, 2004).

Waves, tides, sea spray and storms transported countless photosynthetic microbes from their marine ecosystem onto land. The first Terrabacterium on land faced vicissitudes (Sleep \& Bird, 2008). The successful land colonists, Terrabacteria, evolved into ecosystems of photosynthetic organisms and actinobacteria that weathered exposed rock and formed soil. Anoxygenic photosynthetic ecosystems benefited from efficient weathering and the primary producers acquired ferrous iron as an oxygen acceptor (Sleep \& Bird, 2008). Subsequently, weathering and diagenetic rock alteration affected the geological evolution of the Earth's crust (Rosing et al., 2006).

The transition from anoxygenic to oxygenic photosynthesis took place when the cyanobacteria "learned" how to use water as an electron donor for carbon dioxide reduction. Before that time hydrogen peroxide $\left(\mathrm{H}_{2} \mathrm{O}_{2}\right)$ may have served as a transitional donor, and before that, ferrous iron may have been the original source of reducing power (Olson \& Blankenship, 2004). Borda et al. (2001) showed that pyrite-induced hydrogen peroxide formation from $\mathrm{H}_{2} \mathrm{O}$ might well have taken place in the absence of oxygen on the early Earth. Several authors (Bader, 1994; Rutherford \& Nitschke, 1996; Samuilov, 1997; see also discussion below) have suggested hydrogen peroxide as an early electron donor to photosystem II (PSII).

Cyanobacteria appeared on land (around 2.5 billion years (Ga) ago (Fig. 1.) Battistuzzi et al., 2004; Sleep \& Bird, 2008). Carbon isotope data suggest that autotrophic carbon fixation was taking place at least a billion years earlier (Olson \& Blankenship, 2004). However, it is not possible to determine from the biomarkers alone whether these cyanobacterial ancestors actually carried out oxygenic photosynthesis (Olson \& Blankenship, 2004). Schopf (1993) and Schopf and Packer (1987) have proposed on the basis of morphology alone that the photoautotrophs may have been ancient oxygen producing cyanobacteria. It can be speculated that cyanobacteria generated local and transient dioxygen oases and the need for an oxygen acceptor limited ecosystems, and they have evolved the complex biochemistry required for oxygenic photosynthesis (Sleep \& Bird, 2008; see also discussion below). It can be expected that presence of $\mathrm{O}_{2}$ influenced the redox regulated processes.

It is a widely accepted opinion that the primordial Earth's atmosphere before about $2.45 \mathrm{Ga}$ was anoxic with about $10^{-5}$ of the present atmospheric level (PAL) of molecular oxygen (Farquhar et al., 2007; Kaufman et al., 2007). The majority of geologists believe that the atmosphere started to build up significant quantities of molecular oxygen by about 2.2-2.4 Ga (Cathling et al., 2001) (Fig. 1). Anoxygenic and oxygenic photosynthesis oxidized much of the Earth's crust and supplied sulphate to the ocean. Anoxygenic photosynthesis remained important until there was enough $\mathrm{O}_{2}$ in downwelling seawater to quantitatively oxidize massive sulphides at mid-ocean ridge axes. Dioxygen remained a minuscule component of the atmosphere as long as sulphide was a significantly dissolved species in the shallow ocean (Sleep \& Bird, 2008).

\section{EVOLUTION OF PHOTOSYNTHETIC ELECTRON TRANSPORT SYSTEM}

Some authors suggest that the origin of photosynthesis came much later than the appearance of the last universal common ancestor (LUCA) (Fig. 1). According to this view photosynthesis arose in the Bacteria after they had separated from the Archaea (Olson \& Blankenship, 2004). Molecular genetics indicates that bacteria evolved photosynthesis just once (Sadekar et al., 2006). The evolutionary histories of various classes of antenna/light-harvesting complexes reaction centers RC1 and RC2 in different organisms performing anoxygenic photosynthesis appear to be completely independent (Olson \& Blankenship, 2004). The primitive photosystem might have functioned in the prebiotic phase of evolution (Olson \& Blankenship, 2004). Purple bacterial RC2 and photosystem II (PSII)
Figure 1. Some antioxidative mechanisms during evolution (adapted from Asada, 2000; Bayrhuber \& Kull, 2005).

Fe-SODs probably constitute the most ancient group (Bannister et al., 1991). Mn-SOD certainly evolved from ancestral Fe-SOD, perhaps by way of the cambialistic SODs. Feand $\mathrm{Mn}$-SODs are present both in prokaryotic and in eukaryotic organisms whereas $\mathrm{Cu}, \mathrm{Zn}$-SODs have been found mostly in Eukaryota (Alscher et al., 2002). 
from oxygenic organisms have very similar overall structure and mechanisms (Olson \& Blankenship, 2004). Similar arguments have been presented for the RC1 of green sulphur bacteria (later also including heliobacteria) and photosystem I (PSI) (Olson et al., 1976). The evolution of RC2 was a response to the gradual increase in the redox level of the environment as the best electron donors for $\mathrm{CO}_{2}$ fixation were used up. The modus operandi for most bacteria containing $\mathrm{RC} 2$ is mainly cyclic electron flow that drives ATP production, whereas for the majority of bacteria containing RC1 it is mainly a linear electron flow that reduces ferredoxin (Olson \& Blankenship, 2004) (Fig. 2). The twain Cyanobacterial photosystems evolved by the fusion of two microbes, one possesing RC1 and the other with RC2, which later developed into PSI and PSII, respectively (Xiong et al., 2000; Baymann et al., 2001; Allen \& Martin, 2007).

\section{OXYGENIC PHOTOSYNTHESIS AND REACTIVE OXYGEN SPECIES (ROS)}

The ancestral Earth's atmosphere without oxygen was not reduced, but more neutral, and probably it predominantly contained carbon dioxide $\left(\mathrm{CO}_{2}\right)$ (Kasting, 1993; Shaw, 2008). The emergence of oxygenic photosyntheis was a huge revolution in the young Earth environment, because a new relatively active chemical compound i.e. molecular oxygen appeared.

As photosynthesis oxygenated the environment, the formation of reactive oxygen species (ROS) would have become more common. ROS include mainly singlet oxygen $\left({ }^{1} \mathrm{O}_{2}\right)$, superoxide anion radical $\left(\mathrm{O}_{2}^{-}{ }^{-}\right), \mathrm{H}_{2} \mathrm{O}_{2}$, and hydroxyl radical $\left(\mathrm{HO}^{\circ}\right)$, all of which can cause oxidation of different molecules and in consequence disturbance of normal cellular processes leading to cell death. Therefore, in aerobic organisms an enzymatic antioxidant system against ROS has evolved in order to sufficiently detoxify ROS (Halliwell, 2006; Ślesak et al., 2007). Therefore, the co-evolution of the antioxidant system and oxygenic photosynthesis presents a paradox. Without antioxidants, oxygenic photosynthesis is self-destructive. On the other hand, without oxygenic photosynthesis, there may not have been any selective pressure for the evolution of the antioxidant system. According to the commonly accepted view, aerobic metabolism was possible only after oxygen was released into the Earth atmosphere by oxygenic photosynthesis performed by cyanobacteria, and antioxidant cellular machinery has evolved at the same time as aerobic metabolism and oxygenic photosynthesis. This statement is based on the well-known fact that ROS, mainly $\mathrm{O}_{2}^{-\cdot}$ is a toxic by-product of both respiratory and photosynthetic electron transport chains (De Las Rivas et al., 2004; Halliwell, 2006; Shaw, 2008). Two possible hypotheses concerning the sequence of events in photosynthesis-antioxidant co-evolution can be formulated; 1) if oxygenic photosynthesis evolved first, the large diffusion gradient present in the anaerobic environment would have allowed oxygen to diffuse out of the cells before being converted to ROS, no antioxidant system have been needed until the environment became more oxygenated; 2) alternatively, an antioxidant system may would have evolved first in response to abioticallyinduced ROS generation (Thomas et al., 2008). The latter hypothesis concerning earlier evolution of antioxidants should be seriously considered. Local environments on the young Earth, especially shallow oceans could be enriched in oxygen and ROS induced by UV and cosmic rays. Moreover, as was mentioned above, Borda et al.,
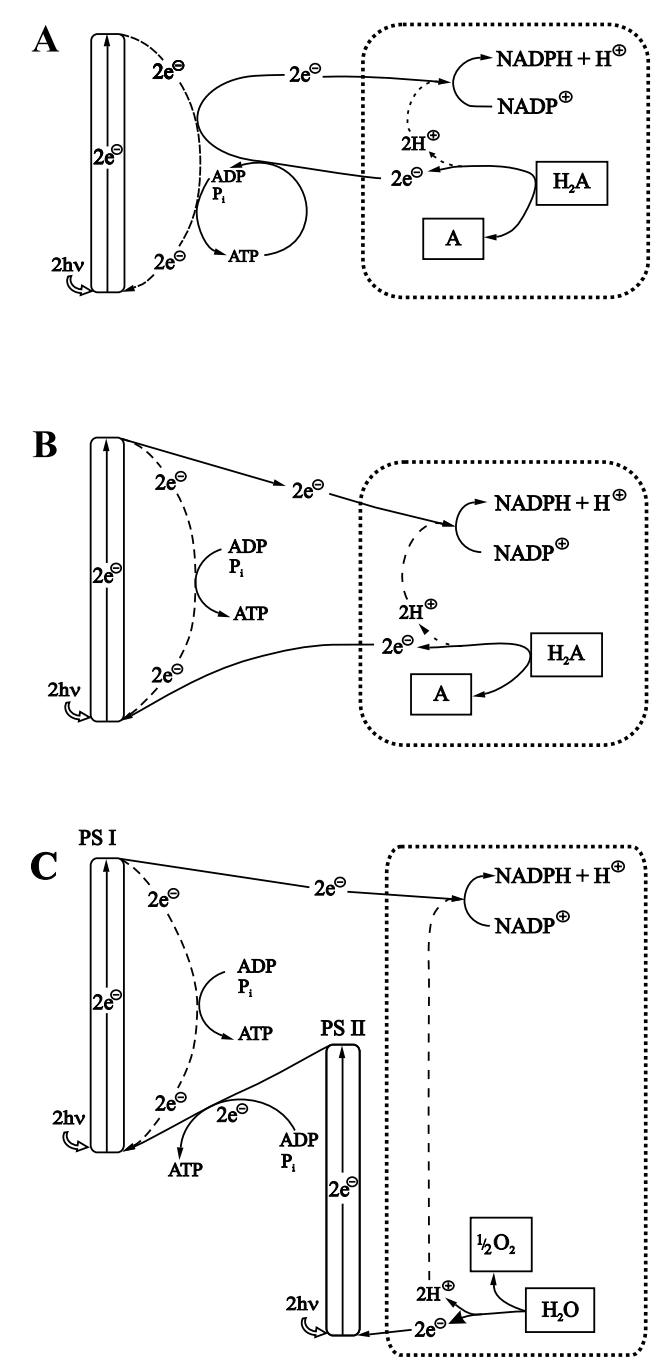

Figure 2. A simplified comparison of the photosynthetic electron transport chain in bacteria, cyanobacteria and green plants performing anoxygenic and oxygenic photosynthesis, respectively.

(A) Purple bacteria do not produce oxygen, the reducing agent involved in photosynthesis in some purple sulphur bacteria is either elementar sulphur and sulphur compounds (hydrogen sulphide, sodium thiosulphate $\mathrm{SO}_{3}{ }^{2-}$ ) or hydrogen and sometime simple organic compounds. The others, called purple non-sulphur bacteria, use mainly simple organic compounds (e.g. malate, succinate) although there are some bacteria that may use hydrogen and sulphur compounds (hydrogen sulphide, sodium thiosulphate) as electron donors. In these processes NAD(P)H is produced in linear electron transport as in green plants (C), this process is also observed in green bacteria (B). (B) In green filamentous bacteria (Chloroflexaceae) and green S bacteria (Chlorobiaceae) - electron are transported in a photosystem similar to PSI in green plants. Green filamentous bacteria as electron donors use hydrogen, hydrogen sulphide and some simple organic compounds; green $\mathrm{S}$ bacteria can use hydrogen, elementar sulphur and sulphur compounds (hydrogen sulphide, sodium thiosulphate, $\mathrm{SO}_{4}{ }^{2-}$ ) (adapted from Lüttge et al., 1999).

(2001) showed $\mathrm{H}_{2} \mathrm{O}_{2}$ formation on pyrite surface in the absence of oxygen. Additionally, the widespread occurrence of basic antioxidant enzymes, such as: superoxide dismutases (SOD), superoxide reductases (SOR), catalases (CAT) and peroxidases (POD) in contemporary species from Bacteria, Archaea and Eucarya domains (Fig. 3), and even in organisms belonging to obligate anaerobes (Brioukhanov \& Netrusov, 2004) might indicate that LUCA was not an obligate anaerobe. LUCA was rather a facultative anaerobe able to remove ROS if it was necessary for its own metabolism. Presence of the anti- 
oxidant system would have protected earlier organisms performing anoxygenic photosynthesis, and supplied pre-adaptation for the subsequent evolution of oxygenic photosynthesis (Thomas et al., 2008). For this reason, most probably ancient cyanobacterial cells were already equipped with some crucial antioxidant enzymes, which they had inherited from moderately anaerobic ancestors.

One of the most important antioxidant enzymes of the first line of defence against ROS is superoxide dismutase (SOD). SOD converts superoxide anion radical $\left(\mathrm{O}_{2}^{-\cdot}\right)$ to hydrogen peroxide and oxygen. Based on the metals present at the active site of an enzyme three main classes of SOD have been identified: iron (Fe-SOD), manganese (Mn-SOD) and copper/zinc (Cu/Zn-SOD) (Alscher et al., 2002). The Mn-SOD and Fe-SOD are phylogenetically related to each other and they are very similar in their primary and tertiary structures, whereas $\mathrm{Cu} / \mathrm{Zn}-\mathrm{SOD}$ shows different structural features (Fink \& Scandalios, 2002; Wolfe-Simon et al., 2005). Fe-SOD has been postulated as an "archaic enzyme" (Schäfer \& Kardinahl, 2003). The increasing content of oxygen in the atmosphere and the occurrence of transition metals on the young Earth might indicate that an iron form is the most "ancient" SOD (Bannister et al., 1991; Asada, 2000). In this scenario, when the early Earth atmosphere was anoxic Fe was abundant in the reduced soluble form $\mathrm{Fe}(\mathrm{II})$. For this reason it would seem that $\mathrm{Fe}(\mathrm{II})$ was the first transition metal present at the active site of the first SOD (Bannister et al., 1991). Later, during biological evolution and increasing level of $\mathrm{O}_{2}$ in the Earth's atmosphere Fe ions were replaced by $\mathrm{Mn}$, and a new SOD using $\mathrm{Cu} / \mathrm{Zn}$ as metal cofactors appeared (Asada, 2000) (Fig. 1).

\section{CHLOROPLASTS ARE ABLE TO CONTROL THE REDOX STATUS}

Foyer and Allen (2003) suggest that "redox signalling" was the first type of sensory regulation that evolved in nature. Sequence similarities in higher plants to cyanobacterial redox signalling components indicate homology and suggest conserved sensory and signalling functions (Forsberg et al., 2001). Photosynthetic organisms have perfected the art of redox control. It is now widely accepted that redox signals are key regulators of plant me-

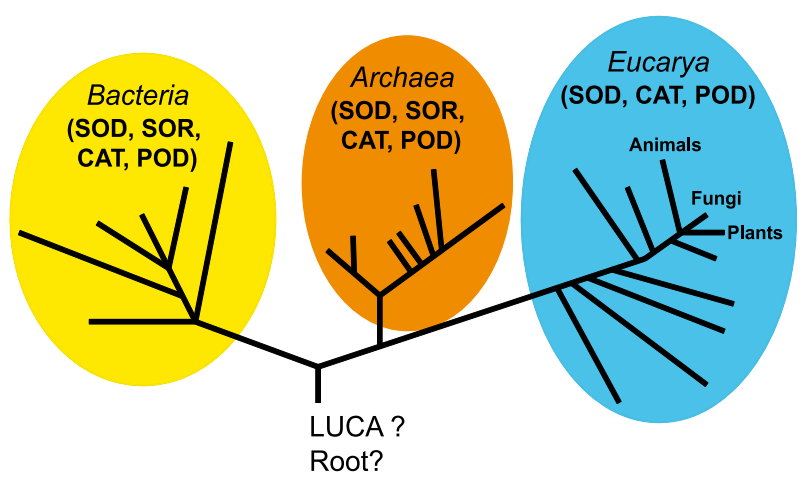

Figure 3. The universal tree of life inferred from comparative analyses of rRNA (Woese, 2000).

The localization of the root of the tree of life and the nature of LUCA are still under debate. The occurrence of basic antioxidant enzymes among the three domains of life is indicated. Abbreviations: CAT, catalase; POD, peroxidase; SOD, superoxide dismutase; SOR, superoxide reductase. tabolism, morphology, development, growth, and eventual death (Foyer \& Allen, 2003).

Plastids are the result of cyanobacterial symbiosis which occurred over 1.2 billion years ago, the present phylogenomic data point to filamentous, heterocystforming (nitrogen-fixing) cyanobacteria as plastid ancestors (Deusch et al., 2008). There is evidence that chloroplast genome encodes proteins whose function and biogenesis are particularly tightly governed by electron transfer (Forsberg et al., 2001). Allen (2003) indicates that it may not be an accident of evolution that chloroplasts retain genes for key proteins of photosynthetic electron transport and he proposes that the reason for this retention is that the chloroplast (and also mitochondrial) genetic system enable them to respond quickly and directly to changes in their internal redox state. This response is necessary to minimise the destructive potential of free radicals (Allen \& Allen, 2008). Allen and Raven (1996) suggest that the present distribution of genes among organellar and nuclear genomes is not so much a "frozen accident" but a result of selective forces favoring movement of some genes from organelles to the nucleus, due to the higher mutation frequencies of organellar genes as result of higher rates of generation of mutagenic ROS (Raven et al., 1994; Allen \& Raven, 1996).

\section{CONTROL OF REDOX STATUS IS NOT UNIFORM THROUGH ALL PHOTOSYNTHESIZING ORGANISMS}

The redox state of the electron transport chain in chloroplasts (specifically the plastoquinone pool) is known to be responsible for post-translational modification, which allows regulation and optimisation of light harvesting in photosynthesis (Karpinski et al., 1999; Allen et al., 1981). The mechanism that couples electron transfer with gene expression is two-component redox signal transduction (Allen, 1993); the redox-controlled kinase that phosphorylates proteins in the light harvesting complex II (LHCII) and thus regulates distribution of excitation energy between the two photosystems of photosynthesis, PSI and PSII (Allen, 2003). LHCII is found in the chloroplasts of all green algae and plants (Allen, 2003). Two-component signal transduction, consisting of sensor kinases and response regulators, is the predominant signalling mechanism in bacteria. This signalling system originated in prokaryotes and has spread throughout the eukaryotic domain of life through endosymbiotic, lateral gene transfer from the bacterial ancestors and early evolutionary precursors of eukaryotic, cytoplasmic, bioenergetic organelles chloroplasts and mitochondria (Puthiyaveetil \& Allen, 2009). The activity of both photosystems can be, at least partly, regulated by the number of LHCII which can migrate between them. In green algae, as much as $85 \%$ of LHCII can migrate to PSI upon state transition (Delosme et al., 1996). The same process was also found in higher plants, although the scale of antenna relocation was much smaller about 20-30\% (Allen, 1992; Escoubas et al., 1995; Lunde et al., 2000). This migration can affect cyclic/linear ETR (electron transport rate) and thus the ATP/NADPH ratio.

Photorespiration which evolved in land plants (Asada, $2000)$ is a consequence of the oxygenation of ribulose1,5-bisphosphate (RuBP) catalysed by ribulose-1,5-bisphosphate carboxylase/oxygenase (RubisCO). Photorespiration not only consumes energy but it can generate metabolites, such as glycine (Madore \& Grodzinski, 1984) used in metabolic pathways for the synthesis of 
glutathione (Noctor et al., 1999). It is known that affinity of RubisCO to $\mathrm{O}_{2}$ has changed during evolution which can be explained by the increasing $\mathrm{O}_{2} / \mathrm{CO}_{2}$ ratio (Lüttge et al., 1999). Photorespiratory processes are responsible for $\mathrm{H}_{2} \mathrm{O}_{2}$ production and increasing photorespiration also means decreasing carboxylation, both can affect the redox status of the cell (Foyer et al., 2009). In both $\mathrm{C}_{4}$ and CAM (Crassulacean acid metabolism) representing about $10 \%$ of all plants are able to concentrate $\mathrm{CO}_{2}$ around RubisCO to avoid strong photorespiration, however, in CAM plants this is true only when a sufficient amount of bicarboxylic acids is available (Miszalski et al., 1998). Some plant families such as Clusiaceae and Aizoaceae are extremely flexible and can switch between $\mathrm{C}_{3}$ and $\mathrm{CAM}$, and this was shown to be parallel to changes in redox status (Miszalski et al., 2001; Lüttge, 2007; Kornas et al., 2009; 2010).

Excess energy excitation (EEE) which cannot be converted into chemical energy can also be dissipated by electron transport to $\mathrm{O}_{2}$ in the Mehler-peroxidase, waterwater cycle pathway or as heat by non-photochemical quenching. Non-photochemical quenching is linked to the formation of zeaxanthin in the xanthophyll cycle and an increased proton gradient across the thylakoid membrane (Ruban \& Horton, 1995). The light-dependent xanthophyll conversion is essential for the adaptation of algae and plants to different light conditions and allows a reversible switch of photosynthetic light-harvesting complexes between a light-harvesting state under low light and a dissipative state under high light (Jahns et al., 2009). Three different xanthophyll cycles have been described in the literature: the violaxanthin cycle $\left(\mathrm{Vx}_{\mathrm{x}}\right.$ cycle; in all plants and green algae) (Siefermann-Harms, 1985), the diadinoxanthin cycle (Ddx-cycle; in some algae) (Stransky \& Hager, 1970) and the lutein-epoxide cycle (Lx-cycle; found in some plant species) (Bungard et al., 1999; García-Plazaola et al., 2007). Xanthophyll cycle regulation is partly under the control of $\mathrm{O}_{2}$ produced in the water splitting system in chloroplasts. Possibly, this could happen at a relatively low atmospheric concentration of $\mathrm{O}_{2}$.

Chloroplasts of algae and higher plants originate from a cyanobacterial endosymbiont, which was originally competent for both photosynthesis and respiration (Jans et al., 2008). Chloroplasts have not entirely lost competence for oxidizing $\mathrm{NAD}(\mathrm{P}) \mathrm{H}$ at the expense of oxygen. In chlororespiration, a thylakoid electron transport pathway involving $\mathrm{NAD}(\mathrm{P}) \mathrm{H}$ :plastoquinone oxidoreductase and plastoquinol oxidase activities takes place (Peltier \& Cournac, 2002). Genes encoding several subunits of a $\mathrm{NAD}(\mathrm{P}) \mathrm{H}$-dehydrogenase (Ndh) involved in a chlororespiration complex homologous to mitochondrial complex I were found in the chloroplast genome of higher plants (Shimada \& Ugiura, 1991). In the plastoquinol $\left(\mathrm{PQH}_{2}\right)$ oxidizing part of the chlororespiratory pathway an alternative plastid terminal oxidase (PTOX) is present which shows homology to the mitochondrial alternative oxidase (AOX) (Carol et al., 1999). This plastid terminal oxidase (PTOX) was also detected in green microalgae in which it was suggested to function as an overflow device for excess PQH2 (Jans et al., 2008). The structure of the Ndh complex has remained obscure, and therefore the role of several Ndh-associated nuclear-encoded proteins either as auxiliary proteins or as structural subunits remains uncertain (Suorsa et al., 2009).

PSII is characterized by its vulnerability to light, which induces its inactivation and subsequent damage and degradation of the D1 reaction center protein.
Many experimental studies have focused on the light-dependent translation of $p s b A$ mRNA, which encodes the D1 protein. In the unicellular algae (Chlamydomonas reinhardtii) translation initiation of D1 may be mediated by the chloroplast redox state and ADP-dependent phosphorylation induced by light (Kim \& Mayfield, 1997). In higher plants translation of D1 is also strictly light regulated (Mühlbauer \& Eichacker, 1998).

\section{HOW DO PLANTS ADAPT TO FLUCTUATING ENVIRONMENTAL CONDITIONS?}

One of the major ways in which plants transmit information about the changing environmental factors is the ROS sensing, producing and scavenging system. Abiotic and biotic stressors regardless of the first target site of their action, affect the cellular balance between different redox buffers and oxidants, called redox homeostasis (Mahalingam \& Fedoroff, 2003; Apel \& Hirt, 2004; Dizengremel et al., 2009). A lot of evidence points to this phenomenon as a common background of most, if not all, environmental stresses perceived not only as a source of oxidative stress, but also as a mechanism controlling the main aspects of plant adaptation to various growth conditions (Foyer \& Noctor, 2005a; 2009). The interplay between ROS production and scavenging determines the steady-state level of ROS in cells, as well as the ROS signature, i.e. the duration, localization, and amplitude of ROS signals conditioning stress responses (Mahalingham \& Fedoroff, 2003; Miller et al., 2008).

The ascorbate-glutathione (AA-GSH) cycle serves as the main antioxidant pathway in plant cells linking the protection against ROS to the redox-regulated plant acclimation response (Kuźniak \& Skłodowska, 2005; Foyer \& Noctor, 2005b) (Fig. 4). The AA-GSH cycle involves successive oxidations and reductions of ascorbate and glutathione catalysed by the enzymes constituting the cycle, namely ascorbate peroxidase (APX, EC 1.11.1.11), monodehydroascorbate reductase (MDHAR, EC 1.6.5.4), dehydroascorbate reductase (DHAR, EC 1.8.5.1) and glutathione reductase (GR, EC 1.6.4.2) (Polle, 2001; Noctor, 2006). It operates in all cellular compartments in which ROS detoxification is needed, i.e. in apoplast, cytosol, chloroplasts, mitochondria and peroxisomes (Foyer \& Noctor, 2003; Potters et al., 2002). Apart from its direct antioxidant role, the AA-GSH cycle functions in ROS sensing and signalling (Foyer \& Noctor, 2005a, 2005b) (Fig. 4).

Many studies have established that ROS and antioxidants could function as intracellular messengers under stress as well as under normal growth conditions. ROS produced by plasma membrane-bound NADPH oxidase have recently been shown to play a role not only in the well-recognized defence responses against biotic stress (Wojtaszek, 1997; Shetty et al., 2008) but also during plant signalling and development (revieved by Laloi et al., 2004). Evidence has been provided that NADPH oxidase produces ROS that activate $\mathrm{Ca}^{2+}$ channels responsible for the formation of the tip-high $\mathrm{Ca}^{2+}$ gradient required for the elongation of root hairs (Foreman et al., 2003). Moreover, ROS, and especially $\mathrm{H}_{2} \mathrm{O}_{2}$, produced by NADPH oxidases have been shown to act as key regulators in physiological processes such as stomatal closure and seed germination known to be under the control of abscisic acid, and root gravitropism controlled by auxins (Apel \& Hirt, 2004; Laloi et al., 2004). This crosstalk of ROS with $\mathrm{Ca}^{2+}$ - and hormone-signalling might provide a link to downstream signalling pathways implicated in a wide range of growth 


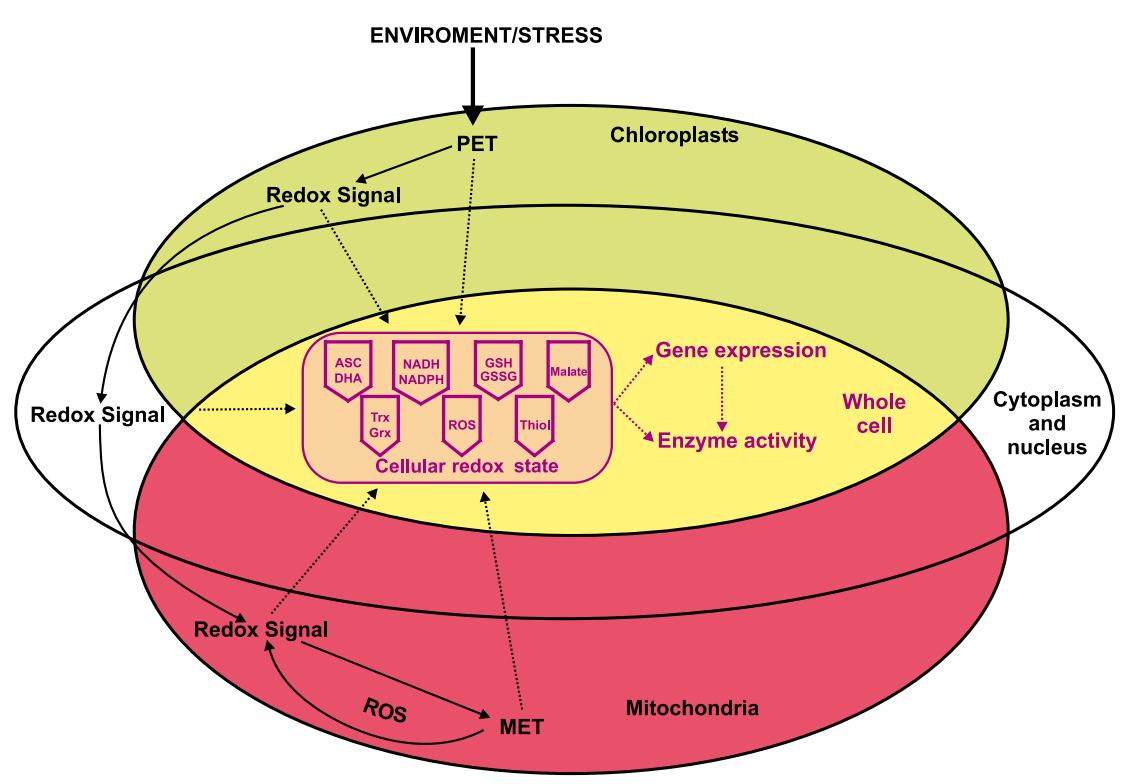

Figure 4. Schematic representation of general pathways of redox regulation that control gene expression and enzyme activity in response to environment-induced changes in photosynthesis (adapted from van Lis \& Atteia, 2004).

Connections between chloroplasts and other cellular compartments are indicated. Abbreviations: ASC, reduced ascorbate; DHA, oxidized ascorbate; Grx, glutaredoxin; GSH, reduced glutathione; GSSG, oxidized glutathione; MET, mitochondrial electron transport; PET, photosynthetic electron transport; ROS, reactive oxygen species; Trx, thioredoxin.

and developmental processes. ROS are also involved in regulation of programmed cell death (PCD) in plants, a phenomenon essential for plant growth, development and adaptation to the fluctuating environmental conditions (Foyer \& Noctor, 2005b). ROS-controlled PCD occurs during the aleurone cell death in germinating seeds of monocots and leaf senescence. The increase in cellular ROS concentration is a prerequisite for induction of the hypersensitive response (HR), one of the best reviewed examples of plant PCD (Levine et al., 1994; Jabs, 1999; Kuźniak et al., 2010). HR is genetically controlled and involves activation of plant host defence-related genes and various defence responses (Lamb \& Dixon, 1997; Suh et al., 2003).

Recent genetic evidence suggests that ROS do not trigger PCD or senescence by causing damage to the cell but they act as signals that activate pathways of gene expression that lead to genetically regulated cell death (Foyer \& Noctor, 2005a; Dietz, 2008). However, the biological activity of ROS in all these developmental and stress processes needs to be viewed in connection with other reactive molecules, especially nitric oxide (NO), that affect both the accumulation and function of ROS (Wilson et al., 2008). It is apparent that the effect of ROS/NO interplay depends on their concentrations and the status of the environment (Hayat et al., 2010).

Most environmental conditions that impose constraints on plant growth and development promote an increase in excess excitation energy (EEE) thus influencing light energy capture and carbon fixation by photosynthesis that are the key determinants for plant life. Stresses affect the photosynthetic electron transport and change the efficiency of light energy fixation (Bechtold et al., 2005; Zhou et al., 2007). Under these stressful conditions imbalance between light energy absorbed through PSII and the ultimate consumption of the photosynthetic electrons through metabolic pathways such as the Calvin cycle, photorespiration and nutrient assimilation occurs. This leads to an increased formation of ROS and to photooxidative stress. For example, drought-, salinity- or low temperature-induced stomatal closure inhibits $\mathrm{CO}_{2}$ assimilation and $\mathrm{NADP}^{+}$regeneration by the Calvin cycle while at the same time the light-driven photosynthetic electron transfer proceeds at high rates leading to an overreduction of the electron transport chain. Consequently, the formation of ROS is initiated at the PSI site by the transfer of electrons to alternative acceptors, predominantly molecular oxygen. Similarly, excitation pressure may be induced by the lack of essential nutrients because of limitations in the availability of electron acceptors such as $\mathrm{NO}_{3}^{-}$or $\mathrm{SO}_{4}^{2-}$ (Wilson et al., 2006). Thus, the photosynthetic apparatus of organisms as diverse as algae, cyanobacteria and higher plants has emerged as a global redox sensor which detects and processes the incoming environmental signals (Huner et al., 1998). Messages originating from chloroplasts influence the expression of defence and regulatory genes thus modulating either the acclimatory process or the execution of PCD.

Three classes of redox signals originating from chloroplasts can be considered to be important in governing the plant adaptive/stress response in natural environments (Pfannschmidt et al., 2001). Class 1 originates from specific redox pairs in the photosynthetic electron transport (PET) chain e.g. the reduced and oxidized plastoquinone and the cytochrome $b_{f} f$ complex. Class 2 depends on the redox state of stromal thioredoxin, $\mathrm{NAD}(\mathrm{P}) \mathrm{H}$, glutathione and ascorbate whereas class 3 is mediated by ROS. These signals act in chloroplasts to ensure the most effective operation of photosynthesis. The redox state of the plastoquinone pool feeds into this mechanism and chloroplast sensor kinase is proposed to monitor the electron transport coupling the redox state of plastoquinone to gene expression in chloroplasts. It passes the information of the electron flux in the PET chain to response regulatory proteins that switch the photosystem genes on and off (Puthiyaveetil \& Allen, 2009). Moreover, redox signals of chloroplast origin reach other compartments and coordinate photosynthesis with other cellular activities exerting a multilevel control on the regulation of gene expression in the nucleus (retrograde signalling) and metabolic activities in mitochondria and cytoplasm (Oelze et al., 2008) (Fig. 4). Retrograde signalling regulates the expression of nuclear organelle genes in response to the metabolic and developmental state of the organelle (Pfannschmidt et al., 2009). Besides the cross-talk between chloroplasts/ mitochondria and the nucleus (Fey et al., 2005; Rhoads \& Subbaiah, 2007), chloroplast-mitochondrion redox communication has been established during plant evolution to coordinate the activities of these two bioenergetic organelles to enable an optimized acclimation response 
(Leister, 2005). For example, the mitochondrial alternative oxidase is involved in the removal of excess photosynthetic reducing power via the malate valve. Excess reducing power can be shuttled out of plastids in the form of malate and the reducing equivalents released by the action of mitochondrial $\mathrm{NADH} / \mathrm{NAD}^{+}$-dependent malate dehydrogenase converting malate to oxaloacetate are consumed by an alternative oxidase preventing the chloroplast from overreduction under unfavourable conditions such as drought and excess light (Scheibe, 2004). Besides malate other products of photosynthetic activity such as glycine or $\mathrm{NAD}(\mathrm{P}) \mathrm{H}$ can also contribute to mitochondrial respiration balancing the cellular energy and redox status (van Lis \& Atteia, 2004). Part of this regulatory mechanism centres around ROS, which are unavoidable by-products of photosynthesis, namely $\mathrm{H}_{2} \mathrm{O}_{2}$ and ${ }^{1} \mathrm{O}_{2}$ generated at PSI and PSII, respectively, that have been associated with the control of nuclear gene expression (Op den Camp et al., 2003; Pfannschmidt et al., 2009). Moreover, photorespiratory $\mathrm{H}_{2} \mathrm{O}_{2}$ has been proposed to have an impact on the transcription of nuclear genes (Vandenabeele et al., 2004).

One of the best characterized mechanisms of redox signalling in photosynthetic organisms is that mediated by dithiol/disulphide exchanges under the control of thioredoxins (TRXs). The redox proteomic approach revealed that in Arabidopsis all 11 enzymes of the Calvin cycle can be regulated by TRXs (Meyer et al., 2005). At present, however, the redox-dependent thiol/disulphide transition extends beyond the well characterized TRXmediated regulation of the Calvin cycle enzymes (Lemaire et al., 2007) and is considered to be one of the most important modifications affecting many cell protein functions (Buchanan \& Balmer, 2005). TRXs are implicated in different aspects of plant life including development and adaptation to environmental changes and stresses (Meyer et al., 2008). Because $\mathrm{H}_{2} \mathrm{O}_{2}$ is a mild oxidant that can oxidize thiol groups, it has been speculated that $\mathrm{H}_{2} \mathrm{O}_{2}$ generated under stress could also be sensed via modification of thiol residues in target proteins (Pitzschke et al., 2006).

The molecular responses to oxidative stress are regulated by redox-sensitive transcription factors. To date, the activation of NPR1 protein (Nonexpressor of Pathogenesis-Related protein 1) is one of the best-known examples. NPR1 was identified as a redox-sensitive transcription factor in Arabidopsis. The reduction of NPR1 preceding gene induction requires an increase in reduced glutathione content and a concomitant shift in the cellular redox environment toward reducing conditions (Mou et al., 2003; Fobert \& Despres, 2005). Under these conditions, NPR1 is reduced from an inactive oligomeric complex localized in the cytosol to an active monomeric state through the reduction of intermolecular disulphide bonds. Monomeric NPR1 is then translocated into the nucleus where it interacts with transcription factors of the TGA class (Mou et al., 2003; Pieterse \& Van Loon, 2004).

\section{CONCLUSIONS}

Most studies on the redox status of the cell were performed on higher plants and algae. We show that antioxidant defences have a long history. Plants can control the cell's redox status using a wide spectrum of different mechanisms and this status is used to control nearly every aspect of plant biology from chemistry to development, growth, and eventual death (Foyer \& Allen, 2003).
All aspects of aerobic life involve ROS, RNS, antioxidants and redox regulation. In recent years our knowledge about the role of oxidative stress and redox regulation of cell functions has increased remarkably with the result that the classical definition of the oxidative stress proposed by Sies in 1985 and describing it as a disturbance in the prooxidant-antioxidant balance in favour of the former, leading to potential damage has been replaced by that of Jones in 2006. This new definition emphasizes the significance of redox regulations and describes oxidative stress as a disruption of redox signalling and control. Various redox-active compounds are involved in these processes, including pyridine nucleotides, thioredoxins, glutaredoxins and other thiol/disulphide-containing proteins. These redox regulations, integrated with the redox-reactions in photosynthesis and respiration to achieve an overall energy balance and to maintain a reduced state necessary for the biosynthetic pathways that are reductive in nature. It underlies the physiological and developmental plasticity in plant response to the environmental signals.

\section{Acknowledgements}

This work was partially supported by the Polish Science Foundation strategic project Welcome 2008/1, the Ministry of Science and Higher Education (Poland) Grant no. N303 356935, and COST projects: 595/N-COST/2009/0, 633/N-COST/09/2010/0, 556/N-COST/2009/0.

This paper would not be possible without the support of Professor Grzegorz Bartosz (Poland).

\section{REFERENCES}

Allen JF (1992) How does protein phosphorylation regulate photosynthesis? Trends Biochem Sci 17: 12-17.

Allen JF (1993) Control of gene expression by redox potential and the requirement for chloroplast and mitochondrial genomes. $J$ Theor Biol 165: 609-631.

Allen JF (2003) State transitions - a question of balance. Science 299: 1530-1532.

Allen JF, Raven JA (1996) Free-radical-induced mutation vs redox regulation: Costs and benefits of genes in organelles. $J$ Mol Evol 42: 482-492.

Allen JF, Martin W (2007) Evolutionary biology: Out of thin air. Nature 445: 610-612.

Allen CA, Allen JF (2008) Redox effects on chloroplast protein synthesis and phosphorylation. In Photosynthesis. Energy from the Sun. Proceedings of the $14^{\text {th }}$ International Congress on Photosynthesis. Allen JF, Gantt E, Golbeck JH, Osmond B, eds, pp 903-907. Springer, Heidelberg.

Allen JF, Bennett J, Steinback KE, Arntzen CJ (1981) Chloroplast protein phosphorylation couples plastoquinone redox state to distribution of excitation-energy between photosystems. Nature 291: 25-29.

Alscher RG, Erturk N, Heath LS (2002) Role of superoxide dismutases (SODs) in controlling oxidative stress in plants. $J$ Exp Bot 53: 1331-1341.

Apel K, Hirt H (2004) Reactive oxygen species: Metabolism, oxidative stress, and signal transduction. Annu Rev Plant Biol 55: 373-399.

Asada K (2000) The water-water cycle as alternative photon and electron sinks. Phil Trans R Soc Lond. B 355: 1419-1431.

Bader KP (1994) Physiological and evolutionary aspects of the $\mathrm{O}_{2} /$ $\mathrm{H}_{2} \mathrm{O}$-cycle in cyanobacteria. Biochim Biophys Acta 1188: 213-219.

Bannister WH, Bannister JV, Barra D, Bond J, Bossa F (1991). Evolutionary aspects of superoxide dismutase: the copper/zinc enzyme. Free Radic Res 12-13: 349-361.

Battistuzzi FU, Feijao A, Hedges SB (2004) A genomie timescale of prokaryote evolution: insights into the origin of methanogenesis, phototrophy, and the colonization of land. Evol. Biol. 4: 44.

Baymann F, Brugna M, Muehlenhoff U, Nitschke W (2001) Daddy, where did (PS)I come from? Biochim Biophys Acta 1507: 291-310.

Bayrhuber H, Kull U (eds) (2005) Evolution. In Linder Biologie. Lehrbuch für die Oberstufe. 21., neu bearbeitete Auflage, p 414. Schroedel Verlag $\mathrm{GmbH}$, Hannover.

Bechtold U, Karpinski S, Mullineaux PM (2005) The influence of the light environment and photosynthesis on oxidative signalling responses in plant-biotrophic pathogen interactions. Plant Cell Environ 28: 1046-1055. 
Borda MI, Elsetinow AR, Schooen MA, Strongin DR (2001) Pyriteinduced hydrogen peroxide formation as a driving force in the evolution of photosynthetic organisms on an early Earth. Astrobiology 1: 283-288.

Brioukhanov AL, Netrusov AI (2004) Catalase and superoxide dismutase: distribution, properties, and physiological role in cells of strict anaerobes. Biochemistry (Moscow) 69: 949-962.

Buchanan BB, Balmer Y (2005) Redox regulation: a broadening horizon. Annu Rev Plant Biol 54: 187-220.

Bungard RA, Ruban AV, Hibberd JM, Press MC, Horton P, Scholes JD (1999) Unusual carotenoid composition and a new type of xanthophyll cycle in plants. Proc Natl Acad Sci USA 96: 1135-1139.

Canfield DE, Rosing MT, Bjerrum C (2006) Early anaerobic metabolisms. Phil Trans R Soc B 361: 1819-1836.

Carol P, Stevenson D, Bisanz C, Breitenbach J, Sandmann G, Mache R, Coupland G, Kuntz M (1999) Mutations in the Arabidopsis gene IMMUTANS cause a variegated phenotype by inactivating a chloroplast terminal oxidase associated with phytoene desaturation. Plant Cell 11: 57-68.

Catling DC, Zahnle KJ, McKay CP (2001) Biogenic methane, hydrogen escape, and the irreversible oxidation of early Earth. Science 293: 839-843.

Dagan T, Martin W (2006) The tree of one percent. Genome Biol 7: 118.

De Las Rivas J, Balsera M, Barber J (2004) Evolution of oxygenic photosynthesis: genome-wide analysis of the OEC extrinsic proteins. Trends Plant Sci 9: 18-24.

Delosme R, Olive J, Wollman FA (1996) Changes in light energy distribution upon state transitions: an in vivo photoacoustic study of the wild type and photosynthesis mutants from Chlamydomonas reinhardtii. Biocbim Biophys Acta — Bioenergetics 1273: 150-158.

Deusch O, Landan G, Roettger M, Gruenheit N, Kowallik KV, Allen JF, Martin W, Dagan T (2008) Genes of cyanobacterial origin in plant nuclear genomes point to a heterocyst-forming plastid ancestor. Mol Biol Evol 25: 748-761.

Dietz KJ (2008) Redox signal integration: from stimulus to networks and genes. Physiol Plantarum 133: 459-468.

Di Giulio M (2007) The tree of life might be rooted in the branch leading to Nanoarcheota. Gene 401: 108-113.

Dizengremel P, Le Thiec D, Hasenfratz-Sauder M-P, Vaultier M-N, Bagard M, Jolivet Y (2009) Metabolic-dependent changes in plant cell redox power after ozone exposure. Plant Biol 11: 35-42.

Ehrenreich A, Widdel F (1994) Anaerobic oxidation of ferrous iron by purple bacteria, a new type of phototrophic metabolism. Appl Environ Microbiol 60: 4517-4526.

Escoubas JM, Lomas M, LaRoche J, Falkowski PG (1995) Light intensity regulation of cab gene transcription is signaled by the redox state of the plastoquinone pool. Proc Natl Acad Sci USA 92: 10237-10241.

Farquhar J, Peters M, Johnston DT, Strauss H, Masterson A, Wiechert U, Kaufman AJ (2007) Isotopic evidence for Mesoarchaean anoxia and changing atmospheric sulphur chemistry. Nature 449: 706-709.

Fey V, Wagner R, Bräutigam K, Wirtz M, Hell R, Dietzmann A, Leister D, Oelmüller R, Pfannschmidt T (2005) Retrograde plastid redox signals in the expression of nuclear genes for chloroplast proteins of Arabidopsis thaliana. J Biol Chem 280: 5318-5328.

Fink RC, Scandalios JG (2002) Molecular evolution and structurefunction relationships of the superoxide dismutase gene families in angiosperms and their relationship to other eukaryotic and prokaryotic superoxide dismutases. Arch Biochem Biophys 399: 19-36.

Fobert PR, Despres C (2005) Redox control of systemic acquired resistance. Curr Opin Plant Biol 8: 378-382.

Foreman J, Demidchik V, Bothwell JH, Mylona P, Miedema H, Torres MA, Linstead P, Costa S, Brownlee C, Jones JDG, Davies JM, Dolan L (2003) Reactive oxygen species produced by NADPH oxidase regulate plant cell growth. Nature 422: 442-446.

Forsberg J, Rosenquist M, Fraysse L, Allen JF (2001) Redox signalling in chloroplasts and mitochondria: genomic and biochemical evidence for two-component regulatory systems in bioenergetic organelles. Biochem Soc Trans 29: 403-407.

Foyer CH, Allen JF (2003) Lessons from redox signaling in plants. Antioxid Redox Signal 5: 3-5.

Foyer CH, Noctor G (2003) Redox sensing and signalling associated with reactive oxygen in chloroplasts, peroxisomes and mitochondria. Physiol Plantarum 119: 355-364.

Foyer CH, Noctor G (2005a) Oxidant and antioxidant signalling in plants: a re-evaluation of the concept of oxidative stress in a physiological context. Plant Cell Environ 28: 1056-1071.

Foyer CH, Noctor G (2005b) Redox homeostasis and antioxidant signaling: A metabolic interface between stress perception and physiological responses. Plant Cell 17: 1866-1875.

Foyer CH, Noctor G (2009) Redox regulation in photosynthetic organisms: Signaling, acclimation, and practical implications. Antiox Redox Signal 11: 862-905.

Foyer CH, Bloom A, Queval G, Noctor G (2009) Photorespiratory metabolism: genes, mutants, energetic, and redox signaling. Annu Rev Plant Biol 60: 455-484.
García-Plazaola JI, Matsubara S, Osmond CB (2007) The lutein epoxide cycle in higher plants: its relationships to other xanthophyll cycles and possible functions. Funct Plant Biol 34: 759-773.

Grassineau NV, Nisbet EG, Bickle MJ, Fowler CMR, Lowry D, Mattey DP, Abell P, Martin A (2001) Antiquity of the biological sulphur cycle: evidence from sulphur and carbon isotopes in 2700 million-year-old rocks of the Belingwe Belt, Zimbabwe. Proc R Soc B 268: 113-119.

Halliwell B (2006) Reactive species and antioxidants. Redox biology is a fundamental theme of aerobic life. Plant Physiol 141: 312-322.

Hayat S, Hasan SA, Mori M, Fariduddin Q, Ahmad A (2010) Nitric oxide: Chemistry, biosynthesis, and physiological role. In Nitric oxide in plant physiology. Hayat S, Mori M, Pichtel J, Ahmad A, eds, pp 1-12. Wiley-VCH Verlag GmbH \& Co. KGaA, Weinheim.

Holser WT, Schidlowski M, Mackenzie FT, Mavnard JB (1988) Geochemical cycles of carbon and sulfur. In Chemical cycles in the evolution of the Earth. Gregor CB, Garrels RM, Mackenzie FT, Maynard JB eds, pp 105-173. Wiley, New York, NY.

Huner NPA, Oquist G, Sarhan F (1998) Energy balance and acclimation to light and cold. Trends Plant Sci 3: 224-230.

Jabs T (1999) Reactive oxygen intermediates as mediators of programmed cell death in plants and animals. Biochem Pharm 57: 231245.

Jahns P, Latowski D, Strzalka K (2009) Mechanism and regulation of the violaxanthin cycle: The role of antenna proteins and membrane lipids. Biochim Biophys Acta 1787: 3-14.

Jans F, Mignolet E, Houyoux PA, Cardol P, Ghysels B, Cuiné S, Cournac L, Peltier G, Remacle C, Franck F (2008) A type II NAD(P)H dehydrogenase mediates light-independent plastoquinone reduction in the chloroplast of Chlamydomonas. Proc Natl Acad Sci USA 105: 20546-20551.

Jones DP (2006) Redefining oxidative stress. Antiox Redox Signal 8: 1865-1879.

Kappler A, Newman DK (2004) Formation of Fe(III) minerals by Fe(II)-oxidizing photoautotrophic bacteria. Geochim Cosmochim Acta 68: $1217-1226$

Karpinski S, Reynolds H, Karpińska B, Wingsle G, Creissen G, Mullineaux P (1999) Systemic signaling and acclimation in response to excess excitation energy in Arabidopsis. Science 284: 654-657.

Kasting JF (1993) Earth's early atmosphere. Science 259: 920-926.

Kaufman AJ, Johnston DT, Farquhar J, Masterson AL, Lyons TW, Bates S, Anbar AD, Arnold GL, Garvin J, Buick R (2007) Late Archean biospheric oxygenation and atmospheric evolution. Science 317: 1900-1903.

Kim J, Mayfield SP (1997) Protein disulfide isomerase as a regulator of chloroplast translational activation. Science 278: 1954-1957.

Kornas A, Fischer-Schliebs E, Lüttge U, Miszalski Z (2009) Adaptation of the obligate CAM plant Clusia alata to light stress: Metabolic responses. I Plant Physiol 166: 1914-1922.

Kornas A, Miszalski Z, Surówka E, Fischer-Schliebs E, Lüttge U (2010) Light stress is not effective to enhanced Crassulacean acid metabolism (CAM). Z Naturforsch C 65c: 79-86.

Kuźniak E, Skłodowska M (2005) Compartment-specific role of the ascorbate-glutathione cycle in the response of tomato leaf cells to Botrytis cinerea. J Exp Bot 56: 921-933.

Kuźniak E, Kornas A, Gabara B, Ullrich C, Skłodowska M, Miszalski Z (2010). Interaction of Botrytis cinerea with the intermediate C3-CAM plant Mesembryanthemum crystallinum. Environ Exp Bot 69: $137-147$.

Laloi C, Apel K, Danon A (2004) Reactive oxygen signalling: the latest news. Curr Opin Plant Biol 7: 323-328.

Lamb C, Dixon RA (1997) The oxidative burst in plant disease resistance. Annu Rev Plant Physiol Plant Mol Biol 48: 251-275.

Leister D (2005) Genomics-based dissection of the cross-talk of chloroplasts with the nucleus and mitochondria in Arabidopsis. Gene 354: 110-115.

Lemaire SD, Michelet L, Zaffagnini M, Massot V, Issakidis-Bourguet E (2007) Thioredoxins in chloroplast. Curr Genet 51: 343-365.

Levine A, Tenhaken R, Dixon R, Lamb C (1994) $\mathrm{H}_{2} \mathrm{O}_{2}$ from the oxidative burst orchestrates the plant hypersensitive disease resistance response. Cell 79: 583-593.

Lunde C, Jensen PE, Haldrup A, Knoetzel J, Scheller HV (2000) The PSI-H subunit of photosystem $I$ is essential for state transitions in plant photosynthesis. Nature 408: 613-615.

Lüttge U (2007) Clusia: A Woody Neotropical Genus of Remarkable Plasticity and Diversity. Ecological Studies, vol. 194. Springer, Heidelberg, New York.

Lüttge U, Kluge M, Bauer G (1999) Botanik. 3. Auflage. Wiley-VCH Verlag GmbH, Weinheim.

Madore M, Grodzinski B (1984) Effect of oxygen concentrations on ${ }^{14} \mathrm{C}$-photoassimilate transport from leaves of Salvia splendens L. Plant Physiol 76: 782-786.

Mahalingam R, Fedoroff N (2003) Stress response, cell death and signalling: the many faces of reactive oxygen species. Physiol Plant 119: 56-68. 
Mat W-K, Xue H, Wong JT-F (2008) The genomics of LUCA. Front Biosci 13: 5605-5613.

Meyer Y, Reichheld JP, Vignols F (2005) Thioredoxins in Arabidopsis and other plants. Photosynth Res 86: 419-433.

Meyer Y, Siala W, Bashandy T, Riondet C, Vignols F, Reichheld JP (2008) Glutaredoxins and thioredoxins in plants. Biochim Biophys Acta 1783: 589-600.

Miller G, Coutu J, Shulaev V, Mittler R (2008) Reactive oxygen signalling in plants. In Annual Plant Reviews: Intracellular Signaling in Plants. Yang Z, ed, vol. 33, pp 189-201. Blackwell, Oxford.

Miszalski Z, Ślesak I, Niewiadomska E, Baczek-Kwinta R, Lüttge U, Ratajczak R (1998) Subcellular localization and stress responses of superoxide dismutase isoforms from leaves in the $\mathrm{C}_{3}$-CAM intermediate halophyte Mesembryanthemum crystallinum L. Plant Cell Environ 21: 169-179.

Miszalski Z, Niewiadomska E, Ślesak I, Lüttge U, Kluge M, Ratajczak $\mathrm{R}$ (2001) The effect to irradiation on carboxylating/decarboxylating enzymes and fumarase activities in Mesembryanthemum crystallinum L., exposed to salinity stress. Plant Biol 3: 17-23.

Mittler R (2006) Abiotic stress, the field environment and stress combination. Trends Plant Sci 11: 15-19.

Mou Z, Fan W, Dong X (2003) Inducers of plant systemic acquired resistance regulate the NPR1 function through redox changes. Cell 113: 935-944.

Mühlbauer SK, Eichacker LA (1998) Light-formation of the photosynthetic proton gradient regulates translation elongation in chloroplasts. J Biol Chem 273: 20935-20940.

Noctor G (2006) Metabolic signalling in defence and stress: the central roles of soluble redox couples. Plant Cell Environ 29: 409-425.

Noctor G, Arisi A-CM, Jouanin L, Foyer CH (1999) Photorespiratory glycine enhances glutathione accumulation in both the chloroplastic and cytosolic compartments. J Exp Bot 50: 1157-1167.

Oelze ML, Kandlbinder A, Dietz KJ (2008) Redox regulation and overreduction control in the photosynthesizing cell: complexity in redox regulatory networks. Biochim Biophys Acta 1780: 1261-1272.

Olson JM, Pierson BK (1986) Photosynthesis 3.5 thousand million years ago. Photosynth Res 9: 251-259.

Olson JM, Blankenship RE (2004) Thinking about the evolution of photosynthesis. Photosyn Res 80: 373-386.

Olson JM, Prince RC, Brune DC (1976) Reaction center complexes from green bacteria. In Chlorophyll Proteins, Reaction Centers and Photosynthetic Membranes, Vol. 28, Brookhaven Symposia in Biology, pp 238-246. Brookhaven National Laboratory, Upton, New York.

Op den Camp RGL, Przybyla D, Ochsenbein C, Laloi C, Kim C, Danon A, Wagner D, Hideg É, Göbel C, Feussner I, Nater M, Apel K (2003) Rapid induction of distinct stress responses after the release of singlet oxygen in Arabidopsis. Plant Cell 15: 2320-2332.

Pace NR (1997) A molecular view of microbial diversity and the biosphere. Science 276: 734-740.

Peltier G, Cournac L (2002) Chlororespiration. Annu Rev Plant Biol 53: 523-550.

Pfannschmidt T, Allen JF, Oelmüller R (2001) Principles of redox control in photosynthesis gene expression. Physiol Plant 112: 1-9.

Pfannschmidt T, Bräutigam K, Wagner R, Dietzel L, Schröter Y, Steiner S, Nykytenko A (2009) Potential regulation of gene expression in photosynthetic cells by redox and energy state: approaches towards better understanding. Ann Bot 103: 599-607.

Pieterse CMJ, Van Loon LC (2004) NPR1: the spider in the web of induced resistance signalling pathways. Curr Opin Plant Biol 7: 456464.

Pitzschke A, Forzani C, Hirt H (2006) Reactive oxygen species signaling in plants. Antioxid Redox Signal 8: 1757-1764.

Polle A (2001) Dissecting the superoxide dismutase-ascorbate-glutathione-pathway in chloroplasts by metabolic modeling. Computer simulations as a step towards flux analysis. Plant Physiol 126: 445-462.

Potters G, De Gara L, Asard H, Horemans N (2002) Ascorbate and glutathione: guardians of the cell cycle, partners in crime? Plant Physiol Biochem 40: 537-548.

Puthiyaveetil S, Allen JF (2009) Chloroplast two-component systems: evolution of the link between photosynthesis and gene expression. Proc R Soc B 276: 2133-2145.

Raven JA, Johnston AM, Parsons R, Kübler JE (1994) The influence of natural and experimental high $\mathrm{O}_{2}$ concentrations on $\mathrm{O}_{2}$-evolving phototrophs. Biol Rev 69: 61-94.

Reysenbach AL, Shock E (2002) Merging genomes with geochemistry in hydrothermal ecosystems. Science 296: 1077-1082.

Rhoads DM, Subbaiah CC (2007) Mitochondrial retrograde regulation in plants. Mitochondrion 7: 177-194.

Rosing MT (1999) C-13-depleted carbon microparticles in $>3700-\mathrm{Ma}$ sea-floor sedimentary. Science 283: 674-676.

Rosing MT, Bird DK, Sleep NH, Glassley W, Albarede F (2006) The rise of continents - An essay on the geologic consequences of photosynthesis. Palaeogeogr Palaeoclimatol Palaeoecol 232: 99-113.

Ruban AV, Horton P (1995) Regulation of non-photochemical quenching of chlorophyll fluorescence in plants. Aust J Plant Physiol 22: $221-230$.
Rutherford AW, Nitschke W (1996) In Origin and Evolution of Biological Energy Conversion. Baltscheffsky H, ed, pp 143-175. VCH Publishers, New York.

Sadekar S, Raymond J, Blankenship RE (2006) Conservation of distantly related membrane proteins: photosynthetic reaction centers share a common structural core. Mol Biol Evol 23: 2001-2007.

Samuilov VD (1997) Photosynthetic oxygen: the role of $\mathrm{H}_{2} \mathrm{O}_{2}$ : a review. Biochemistry (Moscow) 62: 451-454.

Schäfer G, Kardinahl S (2003) Iron superoxide dismutase: structure and function of an archaic enzyme. Biochem Soc Trans 31: 1330-1334.

Scheibe R (2004) Malate valves to balance cellular energy supply. Physiol Plant 120: 21-26.

Schopf JW (1993) Microfossils of the early Archean Apex chert: New evidence of the antiquity of life. Science 260: 640-646.

Schopf JW, Packer BM (1987) Early Archean (3.3-billion to 3.5-billionyear-old) microfossils from Warrawoona Group, Australia. Science 273: $70-73$.

Shaw GH (2008) Earth's atmosphere - Hadean to early Proterozoic. Chem Erde-Geochem 68: 235-264.

Shetty NP, Jørgensen HJL, Jensen JD, Collinge DB, Shetty HS (2008) Roles of reactive oxygen species in interactions between plants and pathogens. Eur J Plant Pathol 121: 267-280.

Shimada H, Ugiura M (1991) Fine structural features of the chloroplast genome: Comparison of the sequenced chloroplast genomes. Nucleic Acids Res 19: 983-995.

Siefermann-Harms D (1985) Carotenoids in photosynthesis. I. Location in photosynthetic membranes and light-harvesting function. Biochim Biophys Acta 811: 325-335.

Sies H (1985) Oxidative stress: introductory remarks. In Oxidative stress. Sies H, ed, pp 1-8. Academic Press, London.

Sleep NH, Bird DK (2007) Niches of the prephotosynthetic biosphere and geologic preservation of Earth's earliest ecology. Geobiology 5: 101-117.

Sleep NH, Bird DK (2008) Evolutionary ecology during the rise of dioxygen in the Earth's atmosphere. Phil Trans R Soc B 363: 26512664.

Stransky H, Hager A (1970) Carotenoid pattern and occurrence of light induced xanthophyll cycle in various classes of algae. Arch Mikrobiol 73: $315-323$

Suh MC, Oh S-K, Kim Y-Ch, Pai H-S, Choi D (2003) Expression of a novel tobacco gene, NgCDM1, is preferentially associated with pathogen-induced cell death. Physiol Mol Plant Pathol 62: 227-235.

Suorsa M, Sirpiö S, Aro E-M (2009) Towards characterization of the chloroplast NAD $(\mathrm{P}) \mathrm{H}$ dehydrogenase complex. Mol Plant 2: 112740.

Ślesak I, Libik M, Karpinska B, Karpiński S, Miszalski Z (2007) The role of hydrogen peroxide in regulation of plant metabolism and cellular signalling in response to environmental stresses. Acta Biochim Pol 54: 39-50.

Thomas DJ, Boling J, Crowell CM, Eubanks LM, McCarthy N, McSpadden T, Rector C, Schuchardt CL, Spurlock CJ, Warrington J (2008) A test of the oxygen paradox using antioxidant-deficient cyanobacteria. Gravitation Space Biol 21: 27-28.

Van Lis R, Atteia A (2004) Control of mitochondrial function via photosynthetic redox signals. Photosynth Res 79: 133-148.

Vandenabeele S, Vanderauwera S, Vuylsteke M, Rombauts S, Langebartels C, Seidlitz HK, Zabeau M, Van Montagu M, Inzé D, Van Breusegem F (2004) Catalase deficiency drastically affects gene expression induced by high light in Arabidopsis thaliana. Plant $J$ 39: 45-58.

Walker JCG (1977) Was the Archaean biosphere upside down? Nature 329: $710-712$.

Wilson KE, Ivanov AG, Öquist G, Grodzinski B, Sarhan F, Huner NPA (2006) Energy balance, organellar redox status, and acclimation to environmental stress. Can J Bot 84: 1355-1370.

Wilson ID, Neill SJ, Hancock JT (2008) Nitric oxide synthesis and signalling in plants. Plant Cell Environ 31: 622-631.

Woese CR (2000) Interpreting the universal phylogenetic tree. Proc Natl Acad Sci USA 97: 8392-8396.

Wojtaszek P (1997) Oxidative burst: an early plant response to pathogen infection. Biochem J 332: 681-692.

Wolfe-Simon F, Grzebyk D, Schofield O (2005) The role and evolution of superoxide dismutases in algae. J Phycol 41: 453-465.

Wong J T-F, Chen J, Mat W-K, Ng S-K, Xue H (2007) Polyphasic evidence delineating the root of life and roots of biological domains. Gene 403: 39-52.

Xiong J, Fischer WM, Inoue K, Nakahara M, Bauer CE (2000 ) Molecular evidence for the early evolution of photosynthesis. Science 289: $1724-1730$.

Zhaxybayeva O, Lapierre P, Gogarten JP (2005) Ancient gene duplication and the root(s) of tree of life. Protoplasma 227: 53-56.

Zhou Y, HM Lam Y, Zhang J (2007) Inhibition of photosynthesis and energy dissipation induced by water and high light stresses in rice. $J$ Exp Bot 58: 1207-1217. 